\title{
Pengembangan bahan ajar E-Learning pada matakuliah Workshop Instalasi Tenaga Listrik prodi S1 Pendidikan Teknik Elektro Universitas Negeri Malang
}

\author{
Suwasono ${ }^{1}$, Hari Putranto ${ }^{2}$, Masdea R. A. Huda ${ }^{3}$ \\ 1. Universitas Negeri Malang, Indonesia | suwasono.ft@um.ac.id \\ 2. Universitas Negeri Malang, Indonesia | hari.putranto.ft@um.ac.id \\ 3. Universitas Negeri Malang, Indonesia | masdea.ra.huda@gmail.com
}

\begin{abstract}
Abstrak
Tujuan dari penelitian ini adalah merancang, membuat, dan menguji kelayakan pengembangan bahan ajar E-Learning pada matakuliah Workshop Instalasi Tenaga Listrik Prodi S1 Pendidikan Teknik Elektro, Universitas Negeri Malang. Model penelitian dan pengembangan yang digunakan mengacu model menurut Sugiyono. Populasi dan sampel penelitian ini adalah Mahasiswa S1 Pendidikan Teknik Elektro Universitas Negeri Malang angkatan 2013 arus kuat. Uji kelayakan terdiri dari validasi ahli materi, validasi ahli media, uji coba kelompok kecil, dan uji coba kelompok besar. Berdasarkan hasil validasi dan uji coba produk, diperoleh kesimpulan bahwa bahan ajar E-Learning pada mata kuliah Workshop Instalasi Tenaga Listrik Prodi S1 Pendidikan Teknik Elektro Universitas Negeri Malang dinyatakan sangat valid sehingga layak digunakan.
\end{abstract}

Kata Kunci

Pengembangan, Bahan Ajar E-Learning, Workshop Instalasi Tenaga Listrik

TEKNO Vol. 27 Issue 2, p147-161 | Jurusan Teknik Elektro, Universitas Negeri Malang, Indonesia | September 2017 Suwasono, H. Putranto, M. R. A. Huda | Pengembangan bahan ajar E-Learning pada matakuliah Workshop Instalasi Tenaga ... 


\section{TEKNO Jurnal Teknologi, Elektro, dan Kejuruan}

http://journal2.um.ac.id/index.php/tekno | ISSN 1693-8739

\section{Pendahuluan}

Teknologi informasi dan komunikasi yang semakin berkembang membawa banyak manfaat di dunia pendidikan. Institusi pendidikan yang menerapkan teknologi informasi dan komunikasi dapat meningkatkan akses, mempercepat proses, serta mengurangi administrasi birokrasi konvensional. Contoh pemanfaatan teknologi informasi dan komunikasi di dunia pendidikan yaitu untuk membuat bahan ajar maupun media pembelajaran yang dapat berguna untuk pembelajaran yang lebih baik.

Salah satu bahan ajar yang mengikuti perkembangan teknologi yaitu bahan ajar e-learning. Menurut Hartley (Rahmasari, 2012) e-learning merupakan jenis pembelajaran yang memungkinkan tersampaikannya bahan ajar ke mahasiswa menggunakan media internet, intranet, atau media jaringan komputer lain. Sedangkan (Nursalam, 2008) mendefinisikan elearning sebagai upaya menghubungkan pembelajar dengan sumber belajarnya yang secara fisik terpisah bahkan berjauhan namun dapat berkomunikasi, berinteraksi atau berkolaborasi secara langsung maupun secara tidak langsung. Siahaan (Wena, 2011) menjelaskan e-learning memiliki tiga fungsi terhadap kegiatan pembelajaran di kelas, yaitu sebagai suplemen pembelajaran yang sifanya pilihan/opsional, sebagai pelengkap (koplemen) pembelajaran, dan sebagai pengganti (substitusi) pembelajaran. Penggunaan e-learning sebagai media pembelajaran semakin meningkat sejalan dengan perkembangan teknologi komunikasi dan informasi. Fasilitas dan infrastruktur juga semakin mendukung dikembangkannya bahan ajar elearning. Jadi sesuai dengan fungsi serta perkembangan teknologi komunikasi dan informasi, maka pembelajaran e-learning sangat dibutuhkan dan tepat untuk dikembangkan.

Universitas Negeri Malang merupakan Universitas yang memiliki visi menjadi perguruan tinggi unggul dan menjadi rujukan dalam penyelenggaraan tridharma perguruan tinggi. Universitas Negeri Malang sudah didukung infrastruktur dan akses internet yang baik. Tiap Jurusan memiliki wifi yang baik seperti pada Jurusan Teknik Elektro yang memiliki potensi adanya fasilitas wifi, Dosen dan Mahasiswa dapat mengoperasikan komputer dan mudah mengakses internet dimanapun dan kapanpun sehingga memungkinkan dikembangkannya bahan ajar e-learning. Terdapat fasilitas e-learning di Universitas Negeri Malang, namun elearning tersebut belum dimanfaatkan secara maksimal karena dibuktikan dengan minimnya dosen yang menggunakan e-learning tersebut. Salah satu matakuliah yang belum memanfaatkan fasilitas e-learning sebagai penyedia bahan ajar yaitu matakuliah Workshop Instalasi Tenaga Listrik.

Workshop Instalasi Tenaga Listrik merupakan salah satu matakuliah yang ada di Prodi S1 Pendidikan Teknik Elektro Universitas Negeri Malang. Berdasarkan Katalog PTE (2014) terdapat enam kompetensi dasar, yaitu: (1) menggunakan syarat-syarat instalasi tenaga berdasarkan PUIL, (2) menggunakan instalasi motor 3 fasa dengan kendali magnetic, (3) menggunakan instalasi motor listrik dengan kendali PLC, (4) memproduksi pemasangan panel daya, (5) memproduksi pentanahan, (6) menggunakan inverter untuk kendali motor listrik.

TEKNO Vol. 27 Issue 2, p147-161 | Jurusan Teknik Elektro, Universitas Negeri Malang, Indonesia | September 2017

Suwasono, H. Putranto, M. R. A. Huda | Pengembangan bahan ajar E-Learning pada matakuliah Workshop Instalasi Tenaga ... 


\section{TEKNO Jurnal Teknologi, Elektro, dan Kejuruan}

http://journal2.um.ac.id/index.php/tekno | ISSN 1693-8739

Dari hasil observasi terhadap Dosen pengampu dan Mahasiswa yang telah menempuh matakuliah Workshop Instalasi Tenaga Listrik di Prodi S1 Pendidikan Teknik Elektro Universitas Negeri Malang, ditemukan: 1) Masih ada mahasiswa yang kesulitan mengerjakan tugas praktikum, sedangkan mata kuliah Workshop Instalasi Tenaga Listrik memiliki potensi adanya jobsheet yang dapat menunjang kegiatan praktikum, 2) Bahan ajar yang digunakan dalam proses perkuliahan belum lengkap, sedangkan Jurusan Teknik Elektro memiliki potensi Laboratorium dengan trainer dan peralatan praktikum yang lengkap, 3) Belum tersedianya bahan ajar yang mengisi e-learning, sedangkan Jurusan Teknik Elektro memiliki potensi adanya fasilitas e-learning, dan 4) Fasilitas wifi di lingkungan Jurusan Teknik Elektro kurang dimanfaatkan secara optimal, sedangkan Jurusan Teknik Elektro sudah memiliki akses wifi yang baik. Dari beberapa penelitian yang relevan, pengembangan bahan ajar e-learning telah banyak dilakukan dan hasilnya "layak untuk digunakan".

Berdasarkan latar belakang serta hasil observasi, maka diadakan penelitian dan pengembangan yang bertujuan untuk merancang, membuat, dan menguji kelayakan bahan ajar elearning untuk matakuliah Workshop Instalasi Tenaga Listrik di Prodi Pendidikan Teknik Elektro Universitas Negeri Malang.

\section{Metode}

1. Model Pengembangan

Penelitian \& Pengembangan bahan ajar e-learning yang dilakukan menggunakan model Sugiyono. Pengembang memilih model Sugiyono dengan alasan langkah-langkahnya sistematis, memiliki beberapa tahapan evaluasi yang baik, serta hasil produknya dapat diproduksi secara massal sehingga tepat digunakan untuk mengembangkan bahan ajar elearning pada matakuliah Workshop Instalasi Tenaga Listrik di Prodi S1 Pendidikan Teknik Elektro Universitas Negeri Malang. Telah dibuktikan dengan beberapa penelitian sebelumnya yang menggunakan model pengembangan Sugiyono dan hasil produknya "layak untuk digunakan". Gambar 1 berikut merupakan tahapan pengembangan menurut Sugiyono (Sugiyono, 2015).

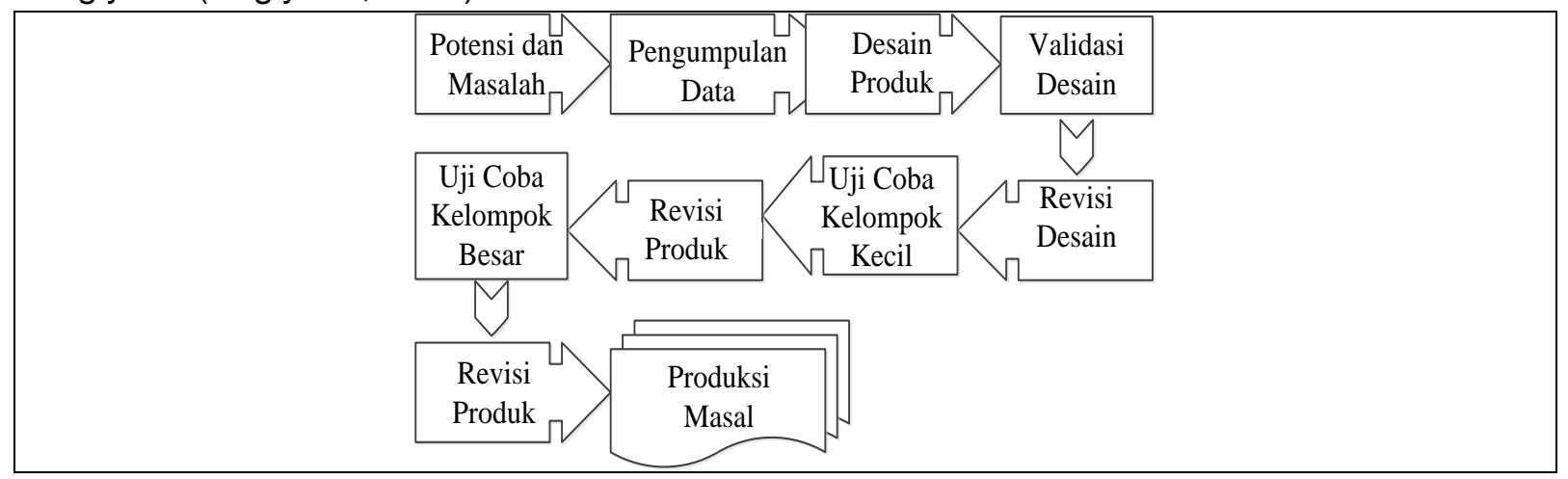

Gambar 1 Langkah-Langkah Model Pengembangan

TEKNO Vol. 27 Issue 2, p147-161 | Jurusan Teknik Elektro, Universitas Negeri Malang, Indonesia | September 2017 Suwasono, H. Putranto, M. R. A. Huda | Pengembangan bahan ajar E-Learning pada matakuliah Workshop Instalasi Tenaga ... 


\section{TEKNO Jumal Teknologi, Eektro, dan kejirvan}

http://journal2.um.ac.id/index.php/tekno | ISSN 1693-8739

a. Potensi dan Masalah

Mencari potensi dan masalah dilakukan dengan observasi kepada dosen pengampu dan mahasiswa yang telah menempuh matakuliah Workshop Instalasi Tenaga Listrik, sehingga ditemukan: 1) Masih ada mahasiswa yang kesulitan mengerjakan tugas praktikum, sedangkan matakuliah Workshop Instalasi Tenaga Listrik memiliki potensi adanya jobsheet yang dapat menunjang kegiatan praktikum, 2) Bahan ajar yang digunakan dalam proses perkuliahan belum lengkap, sedangkan Jurusan Teknik Elektro memiliki potensi Laboratorium dengan trainer dan peralatan praktikum yang lengkap, 3) Belum tersedianya bahan ajar yang mengisi e-learning, sedangkan Jurusan Teknik Elektro memiliki potensi adanya fasilitas e-learning TEUM, dan 4) Fasilitas wifi di lingkungan Jurusan Teknik Elektro kurang dimanfaatkan secara optimal, sedangkan Jurusan Teknik Elektro sudah memiliki akses wifi yang baik.

b. Pengumpulan Data

Data yang dikumpulkan berupa katalog matakuliah Workshop Instalasi Tenaga Listrik dan susunan indikator dari deskripsi kompetensi yang sesuai.

c. Desain Produk

Kegiatan yang dilakukan pada tahap ini yaitu membuat desain bahan ajar modul disertai buku petunjuk modul yang nantinya dimuat di e-learning TEUM mengacu (Daryanto, 2013). Struktur format modul yang digambarkan pada Gambar 2.

\begin{tabular}{|l||l||}
\hline AWALAN & PEMBELAJARAN \\
Kata Pengantar & Kerangka Pembelajaran \\
Daftar Isi & Tujuan pembelajaran \\
Peta Kedudukan Modul & Uraian materi \\
Glosarium & Rangkuman \\
& \\
& T...m.n. \\
\hline
\end{tabular}

Gambar 2. Struktur format modul

Sedangkan struktur format buku petunjuk modul ditunjukkan pada Gambar 3. 


\section{TEKNO Jumal Teknologi, Eektro, dan Keivuruan}

http://journal2.um.ac.id/index.php/tekno | ISSN 1693-8739

\begin{tabular}{|c|}
\hline Kata Pengantar \\
\hline Daftar isi \\
\hline \hline Petunjuk Umum \\
\hline \hline Petunjuk Khusus \\
\hline $\begin{array}{c}\text { Instrumen Evaluasi dan } \\
\text { Penilaian }\end{array}$ \\
\hline $\begin{array}{c}\text { Petunjuk Pengoperasian e- } \\
\text { learning }\end{array}$ \\
\hline Daftar Referensi \\
\hline
\end{tabular}

Gambar 3. Struktur format buku petunjuk modul

d. Validasi Desain

Validasi dilakukan dalam forum diskusi dengan melibatkan ahli media dan ahli materi. Para ahli yang dipilih adalah Dosen Teknik Elektro Universitas Negeri Malang. Tujuan validasi ahli media adalah untuk menilai kelayakan media sedangkan tujuan validasi ahli materi adalah untuk menilai kelayakan isi materi.

e. Revisi Desain

Setelah melakukan validasi ahli media dan ahli materi, maka akan diketahui kekurangan produk. Tujuan tahap ini adalah memperbaiki desain produk berdasarkan acuan dari hasil paparan data validator yang berupa komentar dan sarannya.

f. Uji Coba Produk (Kelompok Kecil)

Uji coba produk dilakukan secara terbatas atau disebut uji coba kelompok kecil. Uji coba ini dilakukan dengan melibatkan Mahasiswa Prodi S1 PTE'2013 arus kuat Jurusan Teknik Elektro Universitas Negeri Malang. Jumlah Mahasiswa sebanyak 10 orang yang dipilih dengan teknik random sampling. (Sugiyono, 2015). Tujuan dari tahap ini adalah untuk mengukur kelayakan media dan penggunaan produk, sehingga jika ada kekurangan maka dapat diperbaiki kembali.

g. Revisi Produk

Setelah melakukan tahap uji coba produk pada kelompok kecil, maka dapat diketahui kekurangan produk. Tujuan dari tahap ini adalah memperbaiki kekurangan produk berdasarkan acuan yang berupa komentar dan saran dari Mahasiswa atau Responden Uji Kelompok Kecil.

h. Uji Coba Pemakaian

Uji coba pemakaian dilakukan dalam ruang lingkup yang luas atau bisa disebut uji coba kelompok besar. Tahap ini merupakan tahap uji coba terakhir. Tujuan tahap ini adalah menguji kelayakan media agar lebih sempurna. Uji coba pemakaian dilakukan dengan melibatkan Mahasiswa S1 PTE'2013 arus kuat Jurusan Teknik Elektro Universitas Negeri Malang. Penentuan jumlah anggota sampel dalam uji coba pemakaian menggunakan pedoman Nomogram Harry King (Sugiyono, 2015). Jumlah 


\section{TEKNO Jurnal Teknologi, Elektro, dan Kejuruan}

http://journal2.um.ac.id/index.php/tekno | ISSN 1693-8739

populasi sebanyak 65 orang. Dikehendaki tingkat kepercayaan terhadap populasi $85 \%$, maka jumlah sampel yang diambil yaitu 0,58 × $65 \times 0,785=29,59$ atau dapat dibulatkan menjadi 30 orang.

i. Revisi Produk

Revisi dilakukan apabila pemakaian kondisi nyata dalam ruang lingkup luas terdapat kekurangan atau kelemahan. Tahap ini bertujuan agar produk yang dikembangkan lebih akurat dan layak digunakan. Pada tahap ini tingkat keefektifan dari produk dapat dipertanggungjawabkan dan diandalkan. Dengan demikian produk ini layak digunakan dalam pembelajaran matakuliah Workshop Instalasi Tenaga Listrik di Prodi S1 Pendidikan Teknik Elektro Universitas Negeri Malang.

j. Produksi Massal

Sugiyono (2013:311) menyatakan pembuatan produk masal dilakukan jika produk yang telah divalidasi/diujicoba dinyatakan efektif dan layak untuk diproduksi masal. Jadi setelah melakukan tahap demi tahap, dengan melalui berbagai uji coba dan revisi produk, maka hasil pengembangan bahan ajar elearning pada matakuliah Workshop Instalasi Tenaga Listrik telah diketahui tingkat kevalidannya dan kelayakannya. Bahan ajar yang dikembangkan dapat berguna sebagai bahan ajar pada proses pembelajaran matakuliah Workshop Instalasi Tenaga di Prodi S1 Pendidikan Teknik Elektro Universitas Negeri Malang.

2. Desain Uji Coba Produk

Desain uji coba dalam pengembangan ini meliputi: a) Uji validasi ahli, b) uji coba kelompok kecil, dan c) uji coba kelompok besar. Tujuan uji coba produk adalah untuk menilai tingkat kelayakan bahan ajar yang dikembangkan. Validasi ahli media dan ahli materi dilakukan oleh Dosen Teknik Elektro, sedangkan uji coba kelompok kecil dan besar dilakukan pada mahasiswa S1 Prodi Pendidikan Teknik Elektro Universitas Negeri Malang. Gambar 4 berikut merupakan desain uji coba dalam pengembangan bahan ajar ini.

\begin{tabular}{|c|c|c|}
\hline $\begin{array}{c}\text { Uji Validasi ahli } \\
\text { 1. Ahli media } \\
\text { 2. Ahli materi }\end{array}$ & $\rightarrow$ & $\begin{array}{c}\text { Uji coba kelompok } \\
\text { kecil } \\
\text { (10 mahasiswa) }\end{array}$
\end{tabular}$\longrightarrow \begin{gathered}\text { Uji coba kelompok } \\
\text { besar } \\
\text { (30 mahasiswa) }\end{gathered}$

Gambar 4. Desain Uji Coba Pengembangan Bahan Ajar E-Learning

3. Subjek Uji Coba

Subjek uji coba merupakan orang yang melakukan validasi produk hingga produk itu layak digunakan. Subjek uji coba penelitian \& pengembangan dijelaskan pada Tabel 1.

pengembangan dijelaskan pada Tabel 1.

TEKNO Vol. 27 Issue 2, p147-161 | Jurusan Teknik Elektro, Universitas Negeri Malang, Indonesia | September 2017 Suwasono, H. Putranto, M. R. A. Huda | Pengembangan bahan ajar E-Learning pada matakuliah Workshop Instalasi Tenaga ... 


\section{TEKNO Jumal Teknologi, Eektro, dan Keivuruan}

http://journal2.um.ac.id/index.php/tekno | ISSN 1693-8739

Tabel 1. Subjek Uji Coba Penelitian \& Pengembangan

\begin{tabular}{rll}
\hline \multicolumn{1}{l}{ No } & Validator & Kriteria \\
\hline 1 & Ahli Materi & $\begin{array}{l}\text { Dosen FT Jurusan TE UM yang mengampu } \\
\text { matakuliah Workshop Instalasi Tenaga Listrik } \\
\text { Dosen FT Jurusan TE UM yang menguasai } \\
\text { bidang ilmu pendidikan dan media pembelajaran } \\
\text { Mahasiswa S1 PTE'13 arus kuat }\end{array}$ \\
3 & $\begin{array}{l}\text { Ahli Media } \\
\text { Mesponden/ }\end{array}$ & \\
\hline
\end{tabular}

4. Jenis Data

Jenis data yang terdapat dalam penelitian \& pengembangan ini berupa data kualitatif dan kuantitatif. Data kualitatif berupa tanggapan dari validator yang berupa kritik maupun saran mengenai bahan ajar yang dikembangkan. Sedangkan data kuantitatif berupa penilaian oleh ahli media, ahli materi, dan responden berupa skor 1 sampai 4 yang dikonversi dalam bentuk persentase hasil penilaian terhadap bahan ajar yang dikembangkan sehingga dapat diketahui tingkat validitasnya.

5. Instrumen Pengumpulan Data

Instrumen pengumpulan data yang digunakan adalah instrument validasi ahli dan instrument penilaian mahasiswa. Validasi dilakukan dengan melibatkan ahli media dan ahli materi untuk mengetahui tingkat validitas produk yang dikembangkan. Instrumen pengumpulan data dari responden/mahasiswa dilakukan dengan menyebarkan angket agar mahasiswa dapat menilai produk yang dikembangkan. Angket berupa angket tertutup dan terbuka. Berikut kisi-kisi instrumen validasi dan uji coba produk:

a. Ahli Media

Validasi ahli media melibatkan Drs. Bapak Suwasono, M.T. yang merupakan dosen jurusan Teknik Elektro yang ahli dibidang ilmu pendidikan dan media pembelajaran. Kriteria validasi ahli media mengacu pada perpaduan (Akbar, 2013), (Wahono, 2006), dan (BSNP, 2007). Kisi-kisi validasi ahli media ditunjukan pada Tabel 2.

Tabel 2. Kisi-kisi Validasi Ahli Media

\begin{tabular}{llll}
\hline No & Aspek Penilaian & Indikator \\
\hline 1 & Kelayakan Penyajian & 1) & Teknik Penyajian \\
& & 2) & Pendukung Penyajian \\
2 & Kelayakan Bahasa & 3) & Komunikatif \\
& & 4) & Keterbacaan \\
3 & Kelayakan Kegrafikan & 5) & Ukuran/Format \\
& & 6) & Desain Kulit \\
& & 7) & Desain Isi \\
\hline
\end{tabular}

b. Ahli Materi

Validasi ahli materi melibatkan Dosen Jurusan Teknik Elektro yang mengampu mata kuliah Workshop Instalasi Tenaga Listrik yaitu Bapak Drs. Hari Putranto. Kriteria Validasi bahan ajar menurut ahli materi berdasarkan kriteria validasi menurut (BSNP , 


\section{TEKNO Jumal Teknologi, Eektro, dan Keivuruan}

http://journal2.um.ac.id/index.php/tekno | ISSN 1693-8739

2007), (Krismasari, 2015), (Susilana ,2008) dan (Sungkono, 2013). Kisi-kisi validasi ahli materi ditunjukan pada Tabel 3.

Tabel 3. Kisi-kisi Validasi Ahli Materi

\begin{tabular}{|c|c|c|}
\hline No & Aspek Penilaian & Indikator \\
\hline 1 & Kelayakan Isi & $\begin{array}{l}\text { 1) Alignment dengan SK dan KD matakuliah, perkembangan, da } \\
\text { kebutuhan mahasiswa } \\
\text { 2) Substansi keilmuan dan life skills } \\
\text { 3) Wawasan untuk maju dan berkembang } \\
\text { 4) Keberagaman nilai-nilai social }\end{array}$ \\
\hline 2 & $\begin{array}{l}\text { Kelayakan } \\
\text { Bahasa }\end{array}$ & $\begin{array}{l}\text { 5) Keterbacaan } \\
\text { 6) Kesesuaian dengan kaidah bahasa Indonesia yang baik dan } \\
\text { benar } \\
\text { 7) Logika berbahasa }\end{array}$ \\
\hline 3 & $\begin{array}{l}\text { Kelayakan } \\
\text { Penyajian }\end{array}$ & $\begin{array}{l}\text { 8) Teknik Penyajian } \\
\text { 9) Penyajian Materi } \\
\text { 10) Penyajian Pembelajaran }\end{array}$ \\
\hline
\end{tabular}

c. Responden/Mahasiswa

Responden/Mahasiswa merupakan subjek uji coba dalam kelompok kecil dan kelompok besar. Kelompok kecil berjumlah 10 Mahasiswa, sedangkan kelompok besar berjumlah 30 Mahasiswa. Mahasiswa tersebut adalah Mahasiswa PTE arus kuat angkatan 2013 yang telah menempuh matakuliah Workshop Instalasi Tenaga Listrik. Kisi-kisi validasi angket untuk Mahasiswa ditunjukan pada Tabel 4.

Tabel 4. Kisi-kisi Angket untuk Mahasiswa

\begin{tabular}{ll}
\hline No & Indikator \\
\hline 1 & Tampilan \\
2 & Penyajian Materi \\
3 & Manfaat \\
\hline
\end{tabular}

Penelitian ini menggunakan skala likert, yang fungsinya adalah mengukur variabel penelitian yang dapat mempengaruhi kelayakan produk. Skala likert ditunjukkan pada tabel 5.

Tabel 5. Skala Likert

\begin{tabular}{cl}
\hline Skor & Keterangan \\
\hline 1 & Tidak setuju / tidak sesuai / tidak jelas / tidak lengkap \\
2 & Kurang setuju / kurang sesuai / kurang jelas / kurang lengkap \\
3 & Setuju / sesuai / jelas / lengkap \\
4 & Sangat setuju / Sangat sesuai / Sangat jelas / Sangat lengkap \\
\hline
\end{tabular}

Penjelasan:

Skor penjumlahan dihitung dengan, (jumlah responden yang menjawab sangat setuju $\times 4)+($ jumlah responden yang menjawab setuju $\times 3$ ) + (jumlah responden yang menjawab tidak setuju $\times 2$ ) + (jumlah responden yang menjawab sangat tidak setuju x1) $=$ skor total. 


\section{TEKNO Jumal Teknologi, Eektro, dan Keivuruan}

http://journal2.um.ac.id/index.php/tekno | ISSN 1693-8739

6. Teknik Analisa Data

Analisis data merupakan proses mencari dan menyusun secara sistematis data yang diperoleh dari hasil observasi, angket, catatan lapangan, dan bahan-bahan lain. Teknik analisa data dalam penelitian dan pengembangan ini disesuaikan dengan jenis data yang diteliti. Data kualitatif yang berupa komentar, saran dan kritik nantinya digunakan untuk dasar revisi bahan ajar yang dikembangkan. Kemudian produk dianalisa kelayakanya untuk mengetahui seberapa valid produk yang dikembangkan tersebut. Rumus berikut digunakan untuk mengetahui kalayakan produk:

$$
\mathrm{P}=\frac{\sum x}{\sum x i} \mathrm{x} 100 \%
$$

Keterangan:

$\mathrm{P}=$ Persentase kriteria hasil subjek uji coba

$\sum x=$ jumlah jawaban skor oleh subjek uji coba

$\sum x i=$ jumlah jawaban maksimal dalam aspek penilaian yang telah ditetapkan

$100=$ konstanta

Kriteria validasi ditunjukan pada Tabel 6.

Tabel 6. Kriteria Validasi

\begin{tabular}{rll}
\hline No & Kriteria & Tingkat Validasi \\
\hline 1 & $85,01 \%-100,00 \%$ & Sangat valid, atau dapat digunakan tanpa revisi \\
2 & $70,01 \%-85,00 \%$ & Cukup valid, atau dapat digunakan namun perlu revisi kecil \\
3 & $50,01 \%-70,00 \%$ & $\begin{array}{l}\text { Kurang valid, atau disarankan tidak digunakan karena } \\
\text { perlu revisi besar }\end{array}$ \\
4 & $01,00 \%-50,00 \%$ & Tidak valid, atau tidak boleh digunakan \\
\hline
\end{tabular}

Dari Tabel 1.6 mengenai kriteria validasi produk yang dikembangkan dapat diketahui sebagai berikut:

- Jika produk yang divalidasi persentasenya $85.01 \%$ - $100.00 \%$, maka produk tersebut sangat valid, atau dapat digunakan tanpa revisi.

- Jika produk yang divalidasi persentasenya $70.01 \%-85.00 \%$, maka produk tersebut cukup valid, atau dapat digunakan namun perlu direvisi kecil.

- Jika produk yang divalidasi persentasenya $50.01 \%-70.00 \%$, maka produk tersebut kurang valid, disarankan tidak digunakan karena perlu revisi besar.

- Jika produk yang divalidasi persentasenya $01.00 \%-50.00 \%$, maka produk tersebut tidak valid, atau tidak boleh dipergunakan. 


\section{TEKNO Junnal Teknologi, Eektro, dan Kejivuan}

http://journal2.um.ac.id/index.php/tekno | ISSN 1693-8739

\section{Hasil}

\section{Hasil Pengembangan}

Hasil pengembangan produk ini berupa bahan ajar modul yang dimuat di media elearning TEUM. Kompetensi yang termuat dalam bahan ajar ini sesuai dengan isi katalog matakuliah Workshop Instalasi Tenaga Listrik Prodi S1 Pendidikan Teknik Elektro Universitas Negeri Malang. Kompetensi yang harus dicapai tersebut diantaranya: (1) Menggunakan syarat-syarat instalasi tenaga sesuai PUIL; (2) Menggunakan instalasi motor 3 fasa dengan kendali magnetic; (3) Memproduksi pemasangan panel daya; 4) Memproduksi pentanahan.

Modul Workshop Instalasi Tenaga Listrik di Jurusan Teknik Elektro Universitas Negeri Malang dibuat menggunakan aplikasi Ms. Word 2010 yang kemudian dikonversi ke bentuk pdf. Struktur modul pada bahan ajar ini diadaptasi dari struktur modul menurut Daryanto (2013:26). Gambar 5 merupakan tampilan modul Mahasiswa, Gambar 6 merupakan tampilan buku petunjuk modul, Gambar 7 merupakan tampilan e-learning TEUM.

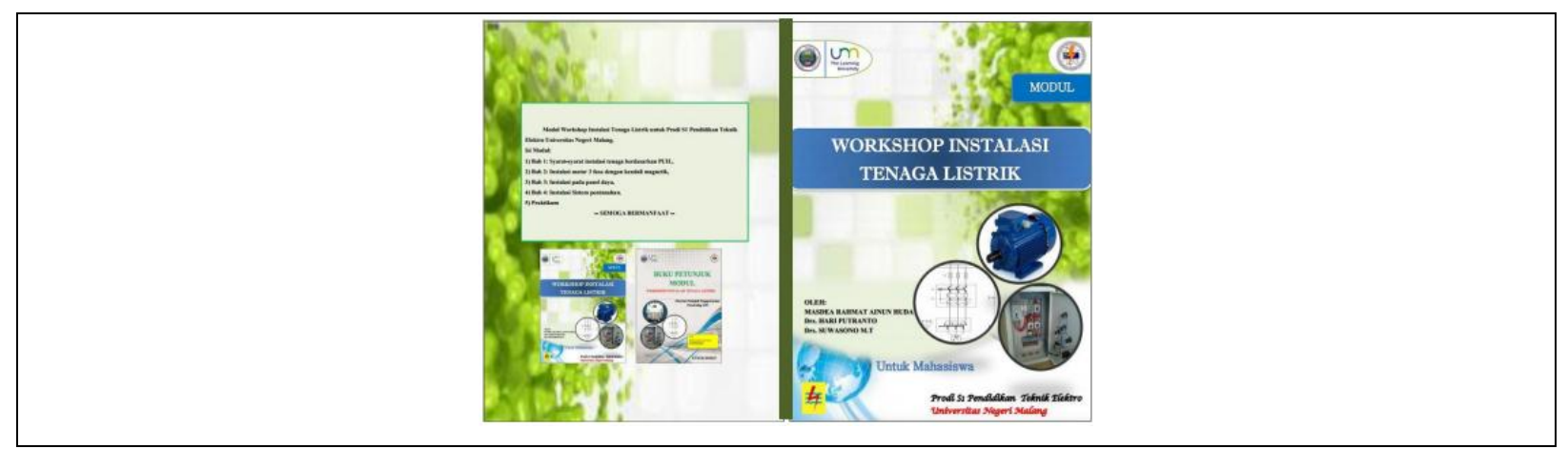

Gambar 5. Modul Mahasiswa

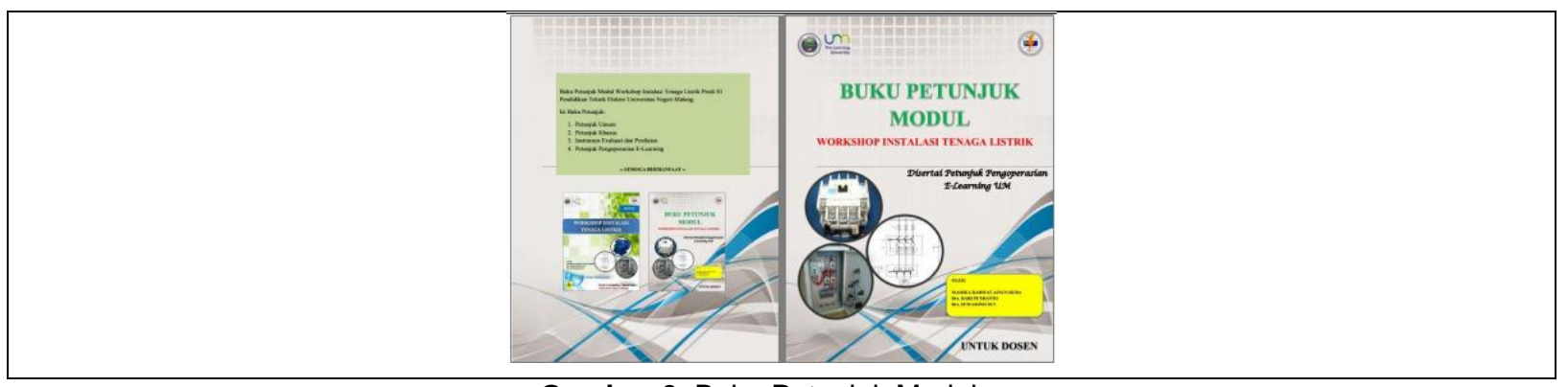

Gambar 6. Buku Petunjuk Modul 


\section{TEKNO Jumal Teknologi, Eektro, dan Keivuruan}

http://journal2.um.ac.id/index.php/tekno | ISSN 1693-8739

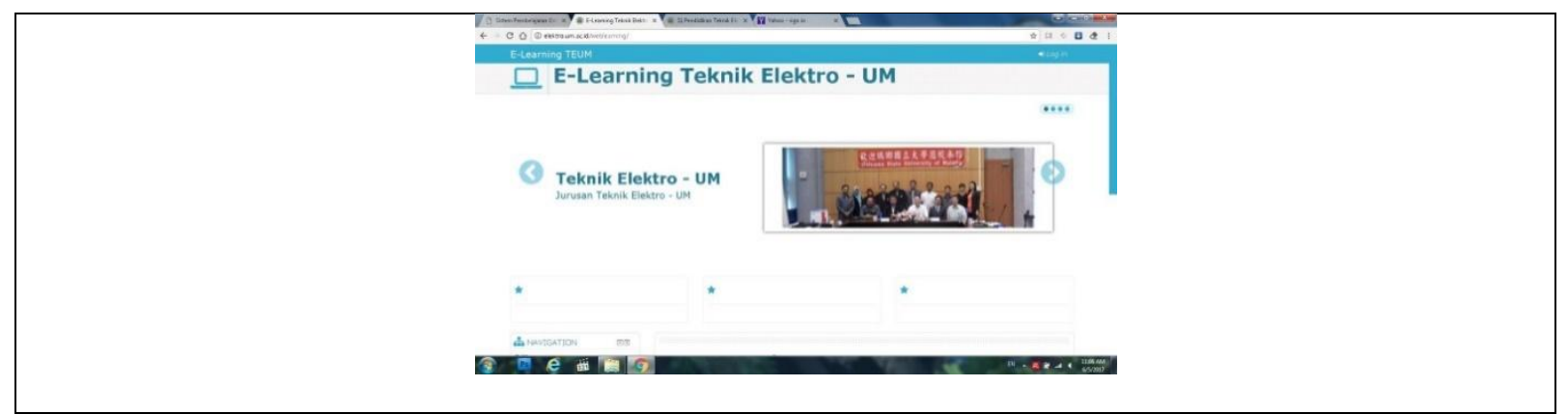

Gambar 7. E-Learning TEUM

\section{Pembahasan}

1. Penyajian Data

a. Hasil Validasi Ahli Materi

Validasi ahli materi melibatkan Dosen Jurusan Teknik Elektro yang mengampu mata kuliah Workshop Instalasi Tenaga Listrik yaitu Bapak Drs. Hari Putranto. Kriteria Validasi bahan ajar menurut ahli materi berdasarkan kriteria validasi menurut (BSNP, 2007), (Krismasari ,2015), (Susilana, 2008) dan (Sungkono, 2013). Data hasil validasi ahli materi ditunjukkan pada Tabel 7.

\begin{tabular}{clcc}
\multicolumn{2}{l}{ Tabel } & 7. Hasil validasi ahli materi \\
\hline No & Aspek Penilaian & $\sum \mathrm{x}$ & $\sum \mathrm{xi}$ \\
\hline 1 & Kelayakan Isi & 29 & 36 \\
2 & Kelayakan Bahasa & 19 & 24 \\
3 & Kelayakan Penyajian & 45 & 48 \\
\hline \multicolumn{2}{c}{ JUMLAH } & 93 & 108 \\
\hline
\end{tabular}

b. Hasil Validasi Ahli Media

Validasi ahli media melibatkan Bapak Drs. Suwasono S.T., M.T. yang merupakan dosen jurusan Teknik Elektro yang mengusai media pembelajaran. Kriteria validasi ahli media mengacu pada perpaduan (Akbar, 2013), (Wahono, 2006), dan (BSNP, 2007). Data hasil validasi ahli media ditunjukkan oleh tabel 8.

Tabel 8. Hasil validasi ahli Media

\begin{tabular}{clcc}
\hline No & Aspek Penilaian & $\sum \mathbf{x}$ & $\sum \mathbf{x i}$ \\
\hline 1 & Kelayakan Penyajian & 45 & 48 \\
2 & Kelayakan Bahasa & 17 & 20 \\
3 & Kelayakan Kegrafikan & 32 & 36 \\
\hline & Jumlah & 94 & 104 \\
\hline
\end{tabular}

c. Hasil Uji Coba Kelompok Kecil

Hasil uji coba kelompok kecil terhadap Bahan Ajar E-Learning untuk Mata Kuliah Workshop Instalasi Tenaga Listrik di Prodi S1 Pendidikan Teknik Elektro Universitas 


\section{TEKNO Jumal Teknologi, Eektro, dan Kejuruan}

http://journal2.um.ac.id/index.php/tekno | ISSN 1693-8739

Negeri Malang berdasarkan kriteria validasi dari BSNP, Sungkono, dan Sitepu yang diperoleh dari pengisian angket. Tabel 9 berikut merupakan data hasil uji coba kelompok kecil.

Tabel 9. Hasil Uji Kelompok Kecil

\begin{tabular}{clcc}
\hline No & Indikator yang Dinilai & $\sum \mathbf{x}$ & $\sum \mathbf{x i}$ \\
\hline 1 & Tampilan & 276 & 320 \\
2 & Penyajian Materi & 407 & 480 \\
3 & Manfaat & 204 & 240 \\
\hline \multicolumn{2}{c}{ Jumlah } & 887 & 1040 \\
\hline
\end{tabular}

\section{d. Hasil Uji Coba Kelompok Besar}

Hasil uji coba kelompok besar terhadap Bahan Ajar E-Learning untuk Mata Kuliah Workshop Instalasi Tenaga Listrik di Prodi S1 Pendidikan Teknik Elektro Universitas Negeri Malang berdasarkan kriteria validasi dari BSNP, Sungkono, dan Sitepu yang diperoleh dari pengisian angket. Tabel 10 berikut merupakan data hasil uji coba kelompok besar.

Tabel 10. Hasil Uji Kelompok Besar

\begin{tabular}{clcc}
\hline No & Aspek yang Dinilai & $\sum \mathbf{x}$ & $\sum \mathbf{x i}$ \\
\hline 1 & Tampilan & 838 & 960 \\
2 & Penyajian Materi & 1259 & 1440 \\
3 & Manfaat & 642 & 720 \\
\hline & Jumlah & 2739 & 3120 \\
\hline
\end{tabular}

\section{Analisa Data}

Dari data hasil validasi ahli materi, validasi ahli media, uji kelompok kecil dan uji kelompok besar diolah menggunakan rumus Pers. (1). Berdasarkan hasil perhitungan, maka hasil persentase validitas menurut ahli materi sebesar $86,111 \%$, ahli media sebesar $90,385 \%$, uji coba kelompok kecil sebesar $85,288 \%$ dan uji kelompok besar sebesar $87,788 \%$. Dari acuan pada tabel 6, maka produk dinyatakan sangat valid. Grafik hasil uji kelayakan produk ditunjukkan pada Gambar 8.

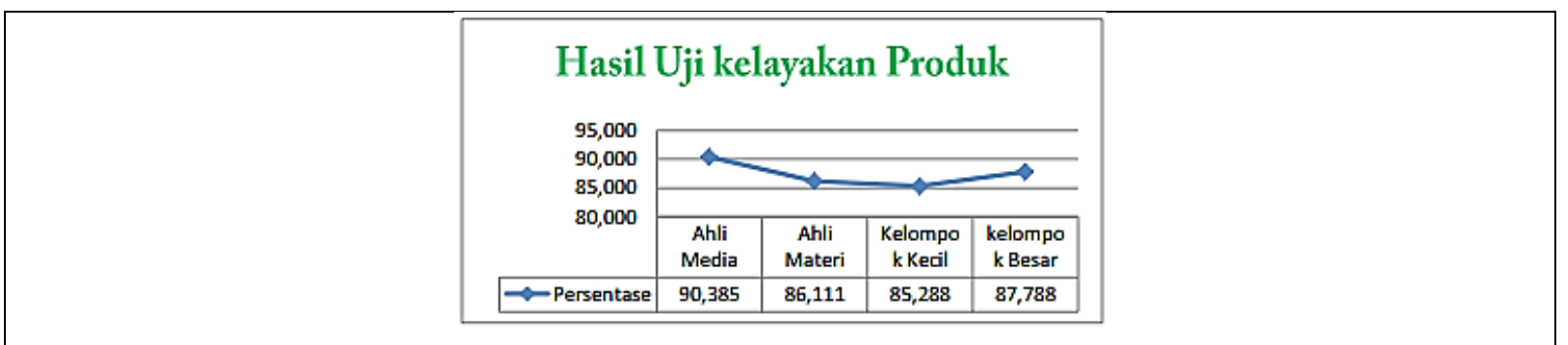

Gambar 8. Hasil Kelayakan Produk 


\section{TEKNO Jurnal Teknologi, Elektro, dan Kejuruan}

http://journal2.um.ac.id/index.php/tekno | ISSN 1693-8739

3. Revisi Produk

Tujuan dari revisi produk yaitu untuk lebih menyempurnakan produk yang berupa bahan ajar yang telah divalidasi oleh para ahli dan uji coba kepada Mahasiswa. Hasil paparan data dari validator ahli materi, ahli media, uji kelompok kecil dan iji coba kelompok besar yang berupa komentar dan saran pada lembar angket digunakan sebagai acuan untuk merevisi produk.

Berdasarkan angket yang diberikan kepada ahli materi diperoleh tanggapan sebagai berikut: 1) Perbaiki bagian petunjuk khusus, 2) Perjelas cetakan khususnya bagian gambar, 3) Online-kan ke E-Learning TEUM.

Berdasarkan angket yang diberikan kepada ahli media diperoleh tanggapan sebagai berikut: 1) Lebih baik setiap akhir BAB diberi rujukan, 2) Buatlah huruf yang lebih bervariasi, 3) Desain gambar pada sampul lebih disesuaikan.

Berdasarkan uji coba kelompok kecil dan uji coba kelompok besar diperoleh tanggapan: 1) Keterangan I/O pada gambar diperjelas, 2) Logo Teknik Elektro lebih baik menggunakan Logo Teknik Elektro UM, 3) pengaturan warna disesuaikan.

\section{Kesimpulan}

Berdasarkan hasil penelitian \& pengembangan yang dilakukan dapat disimpulkan bahwa:

1) Rancangan penelitian \& pengembangan sudah sesuai model Sugiyono, modul sudah sesuai format Daryanto dengan isi materi sesuai katalog, dan e-learning sudah sesuai $e$ learning TEUM.

2) Dihasilkan bahan ajar berupa modul dan buku petunjuk modul Workshop Instalasi Tenaga Listrik. E-Learning TEUM telah diisi dengan modul Workshop Instalasi Tenaga Listrik sehingga sudah bisa diakses oleh Dosen maupun Mahasiswa secara online

3) Hasil uji kelayakan dari ahli materi, ahli media, kelompok kecil dan kelompok besar diperoleh bahwa bahan ajar sudah sangat valid dan layak digunakan.

\section{Saran Pemanfaatan}

Untuk mengoptimalkan pemanfaatan produk, disarankan sebagai berikut:

- Sebaiknya bahan ajar yang telah dikembangkan ini dijadikan sebagai pelengkap untuk menunjang kegiatan perkuliahan Workshop Instalasi Tenaga Listrik pada Prodi S1 Pendidikan Teknik Elektro Universitas Negeri Malang.

- Isi modul sesuai dengan Katalog Prodi S1 Pendidikan Teknik Elektro Universitas Negeri Malang. Mungkin isi materi pada modul kurang lengkap, sebaiknya cari buku yang sesuai dengan daftar referensi pada katalog maupun modul agar lebih memahami materi lebih lanjut. 


\section{TEKNO Jurnal Teknologi, Elektro, dan Kejuruan}

http://journal2.um.ac.id/index.php/tekno | ISSN 1693-8739

\section{Saran Diseminasi Produk} berikut:

Penggunaan produk pada skala yang lebih luas perlu dipertimbangkan hal-hal

- Produk bahan ajar e-learning ini dikembangkan untuk Mahasiswa yang sedang atau telah menempuh mata kuliah Workshop Instalasi Tenaga Listrik pada Prodi S1 Pendidikan Teknik Elektro Universitas Negeri Malang.

- Sebelum disebarluaskan ke ruang lingkup lebih luas seperti disebarluaskan ke kampus lain sebaiknya produk ini dievaluasi kembali dan disesuaikan dengan kondisi atau sasaran yang ingin dituju baik dari segi media maupun isinya.

\section{Saran Pengembangan Produk Lebih Lanjut}

Saran peneliti dalam pengembangan produk lebih lanjut yaitu:

- Perlu dilkukan penelitian lebih lanjut untuk mengembangkan isi dan kemutakhiran konten bahan ajar e-learning ini, misalnya bahan ajar ini ditambahkan dengan metode pembelajaran lain.

- Sebaiknya perlu dilakukan penelitian lebih lanjut untuk mengetahui tingkat efektifitas produk yang dikembangkan ini, karena hasil pengembangan ini hanya sampai tersusunnya produk dengan pengukuran tingkat validitas saja.

\section{Daftar Rujukan}

Akbar, S. 2013. Instrumen Perangkat Pembelajaran. Cetakan Pertama. Remaja Rosdakarya. Bandung.

Borg, W.R, \& Gall, M.D. 1983. Educational Research: An Itroduction, $5^{\text {th }}$. New York: Longman Inc

Darmawan, 2014. Pengembangan E-Learning, Teori dan Desain. Bandung: PT. Remaja Rosdakarya.

Daryanto. 2013. Menyusun Modul: Bahan Ajar untuk Persiapan Guru dalam Mengajar. Yogyakarta: Gava Media.

Depdiknas. 2008. Kurikulum Tingkat Satuan Pendidikan. Jakarta: Dikmenum. Depdiknas.

Lestari, Ika. 2013. Pengembangan bahan Ajar Berbasis Kompetensi: Sesuai dengan Kurikulum Tingkat satuan Pendidikan. Padang: Akademia Permata.

Mulyasa E. 2006. Kurikulum Yang Disempurnakan. Bandung: PT Remaja Rosdakarya.

Nursalam, Fery Efendy. 2008. Penelitian Teknologi Dalam Keperawatan. Jakarta: Salemba Medika.

Rahmasari, Gartika \& Rita Rismiati. 2012. E-learning: Pembelajaran jarak jauh Untuk SMA. Bandung: Yrama Widya.

Ruhimat, Toto. dkk, 2011. Kurikulum dan Pembelajaran. Jakarta. PT Raja Grafindo Persada. Sugiyono. 2015. Metode Penelitian Kuantitatif Kualitatif dan R\&D. Bandung: Alfabeta 


\section{TEKNO Jurnal Teknologi, Elektro, dan Kejuruan}

http://journal2.um.ac.id/index.php/tekno | ISSN 1693-8739

Triyono. 2012. Metode Penelitian Pendidikan. Yogyakarta: Ombak Api

Sukmadinata, Nana Syaodih. 2012. Metode Penelitian Pendidikan. Bandung: Remaja Rosdakarya.

Tim Kurikulum. 2014. Kurikulum Program Studi S1 Pendidikan Teknik Elektro. Malang: FT-UM

Wena, Made. 2011. Strategi Pembelajaran Inovatif Kontemporer: Suatu Tinjauan Konseptual Operasional. Jakarta: Bumi Aksara. 